Article

\title{
Romanian Roma: An Institutional Ethnography of Labour Market Exclusion
}

\author{
Janne Paulsen Breimo ${ }^{1, *}$ and Loreni Elena Baciu ${ }^{2}$ \\ ${ }^{1}$ Faculty of Social Sciences, NORD University, 8049 Bod $\varnothing$, Norway; E-Mail: janne.i.breimo@nord.no \\ ${ }^{2}$ Faculty of Sociology and Psychology, West University of Timisoara, 300223 Timisoara, Romania; \\ E-Mail: elena.baciu@e-uvt.ro \\ * Corresponding author
}

Submitted: 21 December 2015 | Accepted: 5 February 2016 | Published: 29 February 2016

\begin{abstract}
Roma individuals are struggling to access the formal labour market in Romania. Previous research occupied with this issue has traditionally been dominated by quantitative studies of socio-economic indicators that cling to the characteristics of the ethnic group. The study presented here, however, uses institutional ethnography as a method of social inquiry to demonstrate that this issue needs to be studied from a bottom-up perspective. The article illustrates that there are factors connected to how the system of occupational integration operates that must be taken into consideration in order to explain the difficulties Roma individuals face when trying to enter the labour market in Romania. We argue that these structural barriers create and reinforce processes of minoritising that increase marginalization and discrimination and thereby hinder work inclusion for Roma individuals.
\end{abstract}

\section{Keywords}

inclusion; institutional ethnography; labour market; majoritizing; minoritising; Roma; Romania

\section{Issue}

This article is part of a regular issue of Social Inclusion, edited by Professor Ulf R. Hedetoft (University of Copenhagen, Denmark).

(C) 2016 by the authors; licensee Cogitatio (Lisbon, Portugal). This article is licensed under a Creative Commons Attribution 4.0 International License (CC BY).

\section{Introduction}

Roma individuals are largely left out of the labour market across Europe. The situation is severe, as 8 out of 10 of Roma are at risk of poverty, and their income below $60 \%$ of the national median income (European Union Agency for Fundamental Rights [FRA] \& United Nations Development Programme [UNDP], 2012). The situation is especially severe in Romania, since the country ranks at the bottom on most measures of poverty and exclusion within the EU (Alston, 2015). In 2011 , more than $48 \%$ of the Roma population in Romania were unemployed, compared to $7.4 \%$ of the general population (Moisă, Rostaș, Tarnovschi, Rădulescu, \& Andersen, 2013). In addition, only $27 \%$ of the female Roma population were engaged in paid work (Romanian Government, 2015). Furthermore, in $2010,93 \%$ of the Roma population had equal to or less than the minimum income (Dincă, 2014). Previous research on Roma individuals and the labour market is mainly based on quantitative studies focusing on factors such as lack of education, family structures and cultural background as major obstacles for work inclusion (Lazăr et al., 2014; Moisă et al., 2013; Romani CRISS, 2011; Tarnovschi, Preoteasa, Șerban, Bîrsan, \& Hirian, 2012). The knowledge generated from these studies is valuable but they all lean on a top-down perspective. This is problematic as they stress that the obstacles the Roma people face when accessing the labour market cling to characteristics of the individual or the ethnic group. As argued by Surdu and Kovats (2015, p. 14) presenting the Roma as a group which is both 
different and unequal has heightened the stigmatization. With the problem being as critical as it is, a solution has yet to be found (European Commission [EC], 2015; McGarry, 2011). There is a need to try to understand the situation from another angle. One possible way to do this is to access knowledge from below, which is what we will demonstrate in this article. Hence, the purpose of the article is to analyze the labour market situation for Roma individuals in Romania from Roma individuals themselves, and by that contribute with a new understanding about their labour market access.

The article is based on an institutional ethnography of social organisation of work inclusion practices for Roma individuals. Institutional ethnography (IE) is a sociological perspective and a method of inquiry aiming at accessing knowledge from below. The article thereby adds to a growing body of institutional ethnographies, but is unique in its approach to use this method of inquiry to investigate the barriers of Roma individuals entering the labour market. Using institutional ethnography as a method of inquiry to investigate barriers that Roma face when accessing the labour market has-to our knowledge-not been done before. Therefore, by using IE as a method of inquiry, our purpose with this article is to go behind the previously defined reasons for unemployment among the Roma, and to add to the existing knowledge on the problems they face when trying to enter the labour market.

The objective of this study is thereby to investigate barriers identified by Roma individuals themselves and their experiences of barriers towards employment and access on the labour market. By mapping the strategies Roma individuals use to enter the labour market, the main aim is to investigate how the work-in a generous sense meaning anything that people do that takes time, effort and intent (Smith, 2005)-being carried out by the Roma individuals themselves is coordinated with the work done by institutional representatives such as employment agencies, employers, health personnel etc. Hence, our research question is formulated as:

What are the major difficulties experienced in the everyday life of Roma individuals related to accessing the labour market, and how are these experiences/difficulties related to institutional arrangements and practices?

In other words, the aim of this study is to investigate the institutional relations and structural mechanisms underpinning the hindrances and barriers to employment experienced by Roma individuals. Hence, the purpose of this article is to contribute to a growing body of knowledge on the problems of entering the labour market for Roma individuals.

In this project, we have conducted semi-structured interviews with 24 Roma individuals. The underlying in- tention has been that we want to learn from our informants, not about them, by mapping their work knowledge on entering the labour market. This article will illustrate this from four dimensions, which we have called the absence of vocational service institutions, formal requirements, mutual mistrust, and 'stuck in informality'. The rest of this article is divided into four sections. The first section elaborates on the problems of including Roma individuals in the Romanian work force. The second section introduces the theoretical resources and methodological strategies this study rests upon. The third section focuses on how the four dimensions introduced above come into play and how they are related to each other. The article concludes with a discussion of how these dimensions are interconnected and mutually enforced, and can all be traced back to a form of institutionalized and historical discrimination.

\section{Theoretical Framework}

Institutional ethnography (IE) is a 'method of inquiry' (Smith, 2005) that attempts to describe the interface between individuals' experiences and institutional relations (McCoy, 2006, p. 109). The starting point is always from the perspective of a certain group of people. However, the purpose of IE is not to generalize a particular group of people, but rather to illuminate the social and organizational arrangements that "stretch beyond the individual accounts" (Bisaillon \& Rankin, 2013, p. 4). With this focus IE-research endeavours to find and describe social processes that have 'generalizing effects' (DeVault \& McCoy, 2006, p.18). Another important tool often used in IE studies is the concept of work knowledge. Smith (2005, p. 229) defines work in a 'generous sense' as "anything done by people that takes time, effort and intent". Work knowledge is thereby defined as "what people know of in their work and how it is coordinated with the work of others". Mapping these work knowledges is therefore one main objective of IE studies in general and this study in particular. In this article IE is combined with a theoretical understanding of minoritising and majoritizing processes in societies.

The term minoritising as it is introduced by Avtar Brah (1996/2003) suggests that a minority is something that is produced and reproduced in society. She writes that:

"Even when the majority/minority dichotomy is mobilized in order to signal unequal power relations, as is the case in studies that document discrimination against "minorities", its usage remains problematic. This is partly because the numerical referent of this dichotomy encourages a literal reading, reducing the problem of power relations to one of numbers, with the result that the repeated circulation of the discourse has the effect of natu- 
ralizing rather than challenging the power differential." (Brah, 2003, p. 620)

She further argues that the term 'minority' is usually only used on racialized or ethnicised groups. She asks "What category of person is 'minoritised' in a specific discourse?" Zhao (2012) also questions this minority/majority dichotomy and demonstrates how people themselves enact both majoritized and minoritized positions. In other words, these are processes being done (Berg, Flemmen, \& Gullikstad, 2010, p. 20). In this regard the theory of minoritising/majoritising processes speaks to institutional ethnography which is dedicated to the analysis of how everyday experiences of inequality and oppression are being organized (Campbell, 2015, p. 2).

\section{Methods}

To be able to analyze this question we have chosen to use institutional ethnography (IE) as a theoretical and methodological approach. Institutional ethnography, developed by the Canadian sociologist Dorothy E. Smith is a method of inquiry which has as one of its primary goals to "expand people's own knowledge rather than substituting the expert's knowledge for our own" (Smith, 2005, p. 1). Smith (2005, p. 27) argues that all knowledge is socially organized, and that it is important to investigate "how our lives become organized by the institutional foci of the ruling relations mediated by institutionally designed realities." Rather than beginning in theory, the point is to start the investigation in people's own experiences. By following DeVault \& McCoy's (2006, p. 20) advice to identify "experiences or areas of everyday practice that is taken as the experience of whose determinants are to be explored", the objective is to map the 'work knowledge' of involved actors in order to investigate how different practices are coordinated. Work knowledge is understood as "what people know of in their work and how this is coordinated with the work of others". This is based on a generous definition of work, namely, "anything that people do that takes time, effort and intent". "It orients the researcher to what people are actually doing as they participate, in whatever way, in institutional processes" (Smith, 2005, p. 229).

The experiences of 24 Roma individuals is the starting point for an exploration of the hiring practices that converge to shape the opportunities of Roma individuals in the labour market. The informants are 12 men and 12 women between 25-56 years of age, from both urban and rural areas. The interviews have a specific focus on the efforts and work done by the interviewees themselves to obtain and keep employment and their encounters with everything from neighbours and social networks to employers, employment offices and other institutions. An interview guide was used, containing a number of key topics such as: searching for a job, asking for and/or receiving assistance, accessing a job, adapting to a new job, staying in employment, career development, education, strategies used to tackle a lack of income, living conditions and housing and perceptions regarding the employment opportunities of Roma, just to mention a few. The interview guide was used to ensure that all elements were covered, but each interview followed its own dynamic. The research team took great care in adapting the questions to each interviewee and to the interview situation. An emphasis was placed on sensitivity to issues that interviewees themselves brought up, and probing was used to follow up on issues relevant to the study. The research team consists of one group of Romanian researchers from West University of Timisoara, and one group of Norwegian researchers from NORD University. ${ }^{1}$ The interviews were conducted by the Romanian team, in Romanian, and later transcribed verbatim and translated into English, while the Norwegian team has been involved in the planning and the analysis of the interviews.

The recruitment and selection of interviewees followed a two-step process. First, we asked for the collaboration of local institutions and NGOs that provide support and assistance for Roma persons, previously self-identified as such. Our collaborators asked for their beneficiaries' consent in providing us with their information, and thus a list of potential informants was created. From this list we then made a selection to secure a sufficient variation regarding gender, age, area of residence and status in the labour market. The people on the list were informed that such a selection would be made, and all the interviewees selected were informed about the use of the data and provided their written consent on their attendance.

Being dependent on intermediates may involve a certain bias by precluding those with no contact with our collaborators. However, we do not know whether those precluded are more deprived (due to no assistance) or less deprived (did not need assistance) than those potentially included. The use of intermediates also involves some ethical dilemmas. Firstly, we do not know how the relationship between our collaborators and those who were asked to participate actually is, and therefore how voluntary their participation was in the first place. Still, we believe this was the least intrusive way to approach potential interviewees, and the voluntariness of participation was underscored on interviewees' attendance. Secondly, while our study focuses specifically on Roma, there is currently a strong norm to 'de-ethnicize' social problems, especially when

\footnotetext{
${ }^{1}$ The article was elaborated within the E-QUAL-Qualitative Research on Professional Integration of Vulnerable Categories project, financed through the EEA Financial Mechanism 2009-2014. The project is implemented by the West University of Timisoara in partnership with NORD University, Norway.
} 
related to ethnic minorities. There is a fear that juxtaposing certain social problems with a certain ethnicity may reinforce the 'othering' and patronization of the ethnic group in question. We aim to avoid this by specifically addressing the processes and mechanisms through which the problems are being ethically linked (Milikowski, 2000).

Also, 34 semi-structured interviews with key representatives of services providers, authority officials and employers, both and local and national level were conducted. For a better understanding of the whole system, our key informants represented a diversity of professional backgrounds, both at the local (implementation level) and policy-maker's level (e.g., doctors, teachers, employers, representatives of local administration, social services and policy makers).

In order to ensure the confidentiality and anonymity of the informants, all information that could identify them has been omitted. This also includes their communities of residence, for which we have excluded all data that we believe could be used to identify the place.

\section{The Absence of Vocational Service Institutions}

Institutional ethnography more often than not starts with the problems formulated by a group of individuals, whose standpoint the research takes (McCoy, 2006, p. 109). In our project we started out by interviewing Roma individuals, some of whom were unemployed and some of whom were currently employed. The objective of this strategy was to investigate what, according to these individuals, were the difficulties of entering the labour force in Romania. Also, a major objective was to map how their work (in a generous sense) of getting employed was coordinated with the work done by representatives of vocational institutions and other professional actors involved. Hence the main goal was to investigate how these individual experiences were shaped by institutional conditions.

However, the most striking finding in our interviews with Roma individuals was the lack of references to vocational service institutions of various sorts. None of the informants mention this unsolicited, and when asked by the interviewer about their encounters with such organizations, most of them have not been in contact with them. For example 24 year old P. testifies:

"[Have you ever contacted the County Agency of Labor Force Employment or any other institutions that are in charge of employment?] No....From my point of view, my personal point of view, the County Agency does not help find employment. Out of 100 people going and submitting their files to it, I don't know if even 10 or 5 max find a job, from my point of view."

P. comes from an average income family, where both his mother and father are high school graduates and steady job holders. A high school graduate himself, $P$. has held a fair number of jobs so far, considering his age (24 years old). He started working at high school ( $9^{\text {th }}$ grade), seasonally at first (summer jobs). His parents had an important influence in his decision to get a job, encouraging him to have his own pocket money. In spite of the considerable number of jobs he has had so far, P. has never enlisted the help of a specialized agency in order to find employment, using instead his social network, or, as he calls them, acquaintances:

"[I found] the first job given the acquaintances I had and the third like that also. With the help of my acquaintances,...the remaining job...I heard about them from other people, meaning acquaintances"

The term acquaintances is largely used by many other informants, during the interviews, when they name the resources used in order to find employment. In an almost symbolic way, the acquaintances become the substitute for the role which the County Agency of Labour Force Employment was designed to play in the current institutional arrangements.

It appears that one of the main reasons why the Roma do not access the specialized services created in order to provide support for those in search of employment (namely the County Agency of Labour Force Employment) is the lack of trust in the efficacy of these services. The preferred way of finding employment is accessing their own social network, as opposed to requiring assistance from the formal institutions. Moreover, those of the informants who have accessed formal support from such institutions, do not feel that these encounters have been useful. On the contrary, they report on feeling discriminated or abandoned. Hence, the question remains: why are these organizations so distant in their everyday lives and what does this entail? Following the strategy of institutional ethnography we analysed the interviews trying to "keep the institution in view" (McCoy, 2006, p. 109). This means investigating whether there are any institutional barriers segregating the vocational service institutions from the Roma individuals, i.e., what is the social organization of their experiences and which institutional orders come into play (McCoy, 2006, p. 110).

One reason why some of our interviewees are reluctant towards contacting public institutions is their low literacy skills, which seems to be 'exposed' in each encounter the Roma have with the institutions created to provide them support and assistance. According to Smith (2005, p. 101) "institutions exist in that strange magical realm in which social relations based on texts transform the local particularities of people, place and time into standardized, generalized, and, especially translocal forms of coordinating people's activities". However, in some instances these 
transformations of local particularities makes institutions inaccessible for people. For instance, our informants recurrently report on the difficulties of accessing the textualized bureaucracy:

"it is difficult because for those who don't know how to write, they must ask somebody to help them. [Is there somebody in the Town Hall to help you write this application?] There's nobody like this in the Town Hall because they say they're not allowed. [What aren't they allowed?] They aren't allowed to write an application for me. They aren't allowed. All that's left is to ask somebody, a colleague you are with, or to take the application home to be filled in by somebody. And then to go some other time to submit it."

Reports C., a young unemployed female (36 years old), with 4 children, living in a rural community inhabited mostly by the Roma population. She had to give up school after just 4 grades (around the age of 10), because she needed to help around the household, and then never went back to school. The 4 grades she graduated were not sufficient in order to equip her with basic reading and writing skills, so finding a job on a competitive labour market is almost impossible for her, not just because her literacy skills would make a bad impression on the employer, but also because, for her, it is a great struggle even to apply for a job. This is why her employment experience is limited to low unqualified jobs, mostly in agriculture. But, as C. notes later in the interview, even these jobs have become hard to find lately, due to the technological progress and increased use of machinery in agricultural work.

High illiteracy rates among the Roma population is stressed in almost every report or study regarding their social inclusion. Dincă (2014) reports that $25 \%$ of the Roma population in Romania is illiterate. According to the Romanian Government, almost three out of ten Romanian baseline illiterates are of Roma origin (Romanian Government, 2015), in spite of the fact that, officially, Roma represent just $3.3 \%$ of the Romanian population, meaning the illiteracy is almost ten times higher among the Roma citizens than among the nonRoma. Several of our informants argue that the forms that need to be filled in are too complicated for them. For example, A., a former health mediator for Roma inhabitants of a large city, recalls her experiences with the illiterate beneficiaries and their failures in addressing the institutions from the community because they lacked reading and writing skills:

"There were many people that couldn't read or write, many would look at that sheet but didn't know what to do, or how to fill it in....The poor souls, there are many that are illiterate, can't write, can't read, and they'd give those forms to someone else to fill them in. If they couldn't find anybody, they'd forget about it and go back home saying they failed, that's it."

However, the governmental response to this reality consists mainly of general policies and priorities, with little to no effect on actual interventions and practices for and with the Roma-for example, the application form for the 'guaranteed minimum income', a support measure addressed to the poorest citizens (among which a lot are of Roma origin), has no less than 9 pages to be filled in by the applicant. The 9 pages refer to a total number of 21 different general fields (varying from personal data to information regarding the type and amount of income) and sometimes use technical terms (as, for example "hydraulic, mechanical or electrical driven machinery") or legislative references (for example, "merit allowance given based on the Law no. 118 from 2002") without subsequent explanations.

Furthermore, in its legal format, approved at national level, the application form ends with 3 short statements on the applicants' own responsibility (that makes him the exclusive bearer of the responsibility on what was declared), the last one stating that "By signing the present application, I acknowledge that the information declared is correct and complete and that the inadequate declaration of the truth is punished under the penal law ${ }^{2} . "$ Acknowledging the distrust towards public authorities (which we will return to), it is reasonable to believe that this sort of textual 'warning' will have a counterproductive effect on integrating Roma individuals in the labour market. Studying texts such as these is a way of extending "ethnography from people's experience and accounts of their experience into the work processes of institutions and institutional action" (Turner, 2006, p.139). The textual routine mapped out here is thereby part of a minoritising practice that keeps Roma individuals from entering the labour market. Hence, the forms are both inaccessible in their written form as well as being a practice that has exclusionary effects.

\section{Formal Requirements}

Our informants from the Roma population told us stories of the hardships of entering the labour market. Many of them were related to the lack of education, and the fact that the system disfavours people who do not comply with the formal criteria. The first and most important challenge for the Roma population when accessing the formal labour market is represented by the current VET (Vocational Education and Training) Romanian system.

The IVET (Initial Vocational Education and Training)

\footnotetext{
2 Emphasis by the authors.
} 
system in Romania provides 3 levels of qualifications ${ }^{3}$ :

- Qualifications at level I for graduates of School of Arts and Handicrafts or the Apprenticeship Schoo (corresponding EQF level 2);

- Qualifications at level II for graduates of School of Arts and Handicrafts that followed also 1 year plus a compensatory year as an alternative route in the view of continuing their studies in high school (EQF level 3);

- Qualifications at level III for graduates of the upper secondary education (level 4 EQF) or for graduates of technical post-high schools (level 5 EQF).

In order to occupy a qualified position (meaning qualified worker, as opposed to unqualified worker) one has to either graduate IVET or graduate a minimum of 8 years of schooling and a qualification course provided by a public or private CVT (Continuous Vocational Training) provider.

In the case of an ethnic group where more than $75 \%$ of the children do not finish 8 years of study (The World Bank, 2012, cited by Romanian Government, 2015), this requirement presents a major challenge in the process of accessing the labour market, because it hinders the identification of decent jobs and allows them access only to unqualified jobs, often referred to as 'dirty' by the Roma representative voices (in direct reference also to the garbage collection formal jobs, 'traditionally' reserved by the Roma population).

Therefore, for a person with a poor education, not only the job becomes inaccessible, but also the attendance to a qualification course for the position. This could of course be understood as 'lack of education', but it could also be understood as a system that favours education in a way that makes it impossible for people without a formal education to access the labour market. This minoritising practice keeps Roma individuals out of the formal labour market in Romania.

Moreover, the empirical data shows that the 'restorative' measure that should compensate this challenge-the 'Second chance' school programs, that allow adults with no or incomplete education to re-enroll and graduate a certain educational level, is not a measure equally and similarly implemented in all areas (so that all the concerned population could have equal access to it), but it is rather very much dependent on the local will and availability of the schools that organize such programs, and thus they are not permanent nor predictable.

Hence, this accentuates the already existing gap between the Roma (with low levels of formal education) and the non-Roma (holding the ruling model of higher educational achievement) and also leads people with a

${ }^{3}$ You can find more here http://www.eqavet.eu/gns/what-wedo/implementing-the-framework/romania.aspx low level of formal education to the informal labour market, putting them on the outside of all rights granted by being connected to the formal labour market (unemployment benefits/pensions, etc.).

There are also two other important barriers, signalled by the informants, which make accessing the labour market difficult for the Roma ethnics:

First, the lack of political engagement in effectively tackling the 'black labour market' phenomenon-due to their multiple vulnerabilities in accessing employment, the Roma have little access to decent employment and end up in 'informal arrangements' - most of them on the 'black labour market' (meaning without an official employment contract). One of the informants, Mrs. A., reports about her husband's situation on the labour market:

"He goes [to work] where he finds [work]....For the people, they call him. There is a shepherd and he [my husband] helps him sometimes; also, he goes to collect garbage, and anywhere else where there is work. But no, not with an employment contract. He doesn't have [one]."

The couple lives in a rural community, with a significant number of Roma inhabitants and scarce offers of employment. Neither of the two have ever attended school, so a steady job is virtually impossible for them to attain. In spite of the fact that she is 32 years old, Mrs. A. has never been employed. Her parents didn't allow her to attend school, because she was the eldest child and had to care for her 5 younger brothers and help in the household. Mrs. A. and her husband have 2 children and a third on the way, so the main provider (the husband) has to make great efforts to ensure a decent living for his family. As the job offers in the area are almost inexistent, he has to settle with whatever is available, so an 'informal arrangement' (an offer on the black labour market, where the employer holds total control on the terms of the collaboration) is more likely to happen than employment with a legal contract.

This contributes to the perpetuation of the 'vulnerability cycle' in three inter-connected ways: (a) Not having a documented work activity (proven work record), the person cannot access the financial support he would be entitled to when unemployed; (b) When being evaluated for hiring, not being able to present a formal record of his previous experience (even if, in fact, he has such experience), he would probably be rejected by the potential employer; and (c) the lack of an employment contract makes employees very vulnerable in relation to their employers, who, thus, feel free to hire and fire them as they please or, even worse, abuse their position of authority:

“They like you, they keep you, they don't like you, they kick you out...if I could film it so that others 
could see.....And that lady boss comes and looks at you...and she says 'You, you...and the rest home'....She takes the shoes [produced in the factory] and she hits people on the head."

This account belongs to a 37 year old Roma male, living in a rural segregated community, inhabited mainly by Roma population. Due to the fact that a shoe factory is the only potential employer for the low skilled inhabitants in the area, the employees have to stand and take the abuse of the employers, because they have no other alternative for a decent living.

Informal employment appears to be a practice with a widespread use all over Europe (EC, n.d.). While an independent comparative study from 2011 (Hazans, 2011) found that around $11.8 \%$ of the Romanian extended labour force (Roma and non-Roma) were working informally. A report from 2012 released by a Romanian agency (Fiscal Council, 2013) evaluated that the Romanian unregistered work arrangements made up for $27.7 \%$ of the total employees (Roma and non-Roma), business administrators and self-employed. Informal employment is a negative phenomenon with direct effects on the social inclusion of vulnerable categories.

Moreover, a recent article (Preoteasa, 2015) shows that, in Romania, the involvement in informal or quasiformal activities is popular mostly among the low qualified or economically vulnerable, because it allows these categories maintaining the 'socially assisted' status and the financial benefits it entails, while also ensuring an income from paid work.

The second barrier signalled by the informants is that the low level of professional skills make the Roma the most 'easy to replace' labour force, given the recent technological developments-most of the Roma hold a low level of qualification and professional skills, so that, traditionally, their employment paths directed them to the 'traditional Roma handicrafts' (mainly metallurgy, wood work etc.), transmitted from generation to generation, or agricultural work (which required low or no specific training). But, in the last few decades, the demand for such type of work has decreased dramatically, since the traditional Roma handicrafts have remained a market without buyers and the widespread use of machinery in agriculture has no place for manual, unqualified work, as mentioned by. $C$. (the young mother of 4 , who gave up school after the first 4 grades):

"Three years now, that's about when they stopped coming because now they have machinery. To plant potatoes, to take out the potatoes, to harvest the corn, to cut the corn cobs, they have machinery and they no longer need people."

Many Roma ethnics, all over Romania, are in the situation of C.-holders of obsolete skills, which are no longer required by employer or customers (Research
Institute for Quality of Life, 2010; Vincze et al., 2011), and who are thus left with very few opportunities to earn a decent living.

Left outside the labour market, some of the respondents reported using a range of strategies to make a niche for themselves in the work force, by activating individual survival strategies and using their creativity and informal support networks. However, the empirical data shows that there are many legislative and bureaucratic obstacles the Roma have to overcome in order to access the formal labour market in Romania and get a decent job. Voicu (2007, p.10) also states lack of identity documents and ownership titles is a major hindrance for work integration.

\section{Mutual Mistrust}

This difficulty of accessing a lot of jobs on the formal labour market is also connected to the lack of trust between the representatives of the Roma individuals we have interviewed and the representatives of various institutions. In the interviews conducted among the Roma individuals, one of the main findings is as earlier reported the lack of reported encounters with institutional representatives. As mentioned before, none of the interviewees tells about such encounter without being asked, and when inquired, most of them say that they have not been in contact with any public agencies of vocational assistance. Asked why such encounters are so rare or even absent from their experience, most of them report that they do not see the use of it, and/or that they feel discriminated against in their meetings with them. This experienced discrimination and the cultural stereotypes that exist towards Roma individuals also lead to an objection against reaching out to public institutions in general. One woman from the Roma community, former health mediator employed by the municipality of a large city to keep contact and mediate the relations of the Roma community with the public institutions, tells a story about her experience with this mistrust towards public officials:

“There was one family, poor people, I'll never forget them, the child was 22 years old and the child had his own children, and his mother had to come because well, I got him an ID card, but first I had to get his birth certificate and then the ID card and she, the poor soul, was from Fratelia (neighbourhood), they were gypsies and she was so frightened and told me 'But what if they arrest me now?'. I told her they wouldn't do that because I'd do the talking, she'd just be there, next to me, in the room, and she' $d$ keep tormenting herself saying 'I'm afraid they'll arrest me, look there's the Police and they'll come and take me away.' I told her nobody would arrest her for not getting an ID card or a birth certificate for her son." 
This lack of trust is often related to the fear of having their children taken away from them. Alston (2015) states that institutionalization of children due to poverty still plays a significant role in Romania, and $40 \%$ of children placed in institutions are due to poverty. The mistrust in public officials is connected to a long history of discrimination against Roma persons, not only in Romania, but across Europe.

This lack of trust in the role of the formal institutions, which appears as a major issue in almost every interview, creates a metaphorical imbalance, or dilemma, in the life of Roma individuals - there is little or no trust in the public institution, but, at the same time, the public institution regulates more and more aspects of our private life (income, education, spending, parental skills, etc.) The solution to the 'mistrust dilemma' is provided also by the interviewees, and consists in overcompensating with trust in other less formal institutions (like, for example, the social network), which will be presented in the following section.

Following institutional ethnography, our aim was to investigate whether this lack of trust could be traced to organizational practices in some way or another. What we found was that this lack of trust was also found in the interviews with officials working in employment agencies. When asked what they think is the main reason for Roma persons being left out of the labour market all of them answer in various versions of 'lack of motivation'. One representative of a public employment agency states that:

"From what I have noticed, disabled individuals wish very much to be integrated (on the labour market), but the Roma ethnics do not want to be employed."4

Most of the representatives from the public employment agencies stated similar opinions, such as:

"There are individuals who prefer to settle with the social welfare income, than to work.... Honestly, my personal opinion is that a person with disabilities tries to find employment more than a Roma person....The Roma are lazy." ${ }^{5}$

The interviewee that made this statement has been, for over 10 years, employed at a public institution that has the mission to support, indiscriminately, the unemployed in finding and accessing appropriate employment, by providing information, counselling and mediation services and assisting them to make contact with potential employers.

Other similar informants argued that "they prefer to stay at home" or "it is also a matter of the environment in which they live and their culture regarding

\footnotetext{
${ }^{4}$ Emphasis by the authors.

${ }^{5}$ Emphasis by the authors.
}

work". Thus, it is very clear that the interviews with the public employment system (PES) employees reflect a consolidated image of the Roma as 'unwilling to work', that ultimately makes them undeserving of the help provided by such institutions. In a market defined by competition, such as the current labour market, any opportunity or challenge provided by the context (such as the bias of the case manager towards the beneficiary, as a representative of a group of 'others') can have a major impact on an individual's achievement.

This mentality not only constructs a stereotype supporting the concept of inferior other that is ultimately shared and reinforced by the PES employees, but also, in their internal circle and organizational culture, motivates the low level of involvement of the PES with this category of potential beneficiaries. Subsequently, this mistrust and categorizing has minoritising effects that continues to marginalize Roma individuals. Consequently, it also reinforces the mistrust felt by this groups of people themselves when approaching these vocational service institutions.

\section{7. 'Stuck in Informality'}

The lack of trust towards public institutions also leads to the use of informal contacts, as the single available solution to the 'mistrust dilemma', when approaching the labour market.

When asked about how they entered the labour market all those in employment consistently report that they have had some kind of informal contact who spoke for them or vouched for them and thereby got them connected to an employer. This strategy is probably both caused by actual experienced discrimination, but also by a belief that employers are sceptical towards employing Roma individuals in general. Hence, the fear of being discriminated becomes a barrier in itself. Shan (2013) argues that this kind of 'network-dependent hiring schema' hampers immigrants' employment outcomes, because their social networks tend to be familyand ethnicity-based. Although Roma individuals could not be regarded as immigrants in the European states they reside in, they share some of the problems when it comes to inclusion in work and society (Costi, 2010). It could be seen that they have an even worse situation, due to the fact that they lack a 'mother-country' that could support their cause (Halwachs, 2005).

Most of the informants who had succeeded to enter the labour market had relied on informal contacts in order to get access. As we recall from the testimony of $P$. (24 years old male), presented in a previous section of our article, he mentioned that most of the jobs he has attained in his life have been with the help of informal contacts (i.e. people he knew privately), who he called acquaintances:

"[I found] the first job given the acquaintances [I 
had] and the third that way also, [by the help] of my acquaintances, the forth job, at the hotel, at the hotel I found it in Publitim (local newspaper)..., and the remaining jobs I could say that I've heard of them from certain individuals, meaning acquaintances."

The testimonies of other informants back up this account. For example, M., 26 years old male, uses the exact same terminology when recalling his most important sources of support in finding employment

"[I got the job] by the help of acquaintances, first by the help of acquaintances....People must know you, they must trust you, a person that...must represent you."

The acquaintances thus serve as a replacement of what should be the role of the public institution. The interviewees feel uncomfortable when not being represented by an 'acquaintance', probably because they already know they will be perceived not as a single individual, with his/her own strengths and flaws, which are to be discovered over time, but as representatives of a group, with already known strengths and flaws, according to the general perception of the majority, flaws that usually render them unemployable. Only at this point in the argumentation can we fully understand the role of the 'acquaintance' - to testify or vouch that the individuals in question are not as you may think (knowing he/she is a Roma person), but is different than the pattern, the stereotype, the other Roma. In this way, the function of the referee, or the 'acquaintance' is not public-he does not represent the Roma collectivelyhe represents one Roma individual. The individual representation and inter-personal experience is so important, that it stands out throughout all testimonies collected: with very rare exceptions, the Roma informants almost never mention the name of the institutions they accessed, but most of the time, they recall the first names of the individual who they were in contact with. Basically, for our interviewees, the entire interaction with an institution (be it medical, social, or employment-related) is reduced to the experience they had with the individual(s) they were in contact with.

The testimonies illustrate that the Roma feel that they need someone to represent them in the labour market. This individual has to be someone who holds respect in the community. According to the testimonies of the Roma informants, the 'informal network support' model is mainly reinforced by two concurring factors: (1) the lack of trust in the public institutions, as presented in the previous chapters, and (2) the fear of being discriminated against and/or humiliated in their interactions with potential employers, if they would go by themselves, as it happened to some of the ones who 'dared' to represent themselves in front of the employer. Most of them report discriminatory encoun- ters and stated that "they probably noticed that I wasn't Romanian, that I am of a lower nationality" or "because I'm a gypsy that's why". One young female (24 years) reports on the experiences of her husband with accessing the labour market:

"People also look at your nationality, what nationality you are. For example, my husband tried to go somewhere to a company as a driver, because he's a driver, and they didn't hire him because he is a Romani."

When the refusal is not accompanied by an explanation on why the person did not get the job, the representation of the individual about the entire application process suddenly has a gap in it, so the applicant is free to imagine anything he/she wants in order to compose a reasonable explanation and fill the gap. It is very likely that the most 'at hand' explanations would be those that have already been invoked by the other community members.

The vivid dissemination of such examples, especially when invoked against the examples of the better approach of being represented by someone else (which could be almost considered as a good model practice in the oral accounts of finding employment), has the effect of actively keeping the Roma 'stuck in the informality', when approaching the labour market. This practice has long lasting effects not only on the labour market situation of the Roma themselves (who, in this way, end up mostly in informal arrangements, mainly on the 'black labour market', as presented previously), but also on the institutional policies and arrangements designed to support Roma employment: if their efforts of searching for employment remain undocumented, they are invisible to the PES representatives and continue feeding the 'lazy, unmotivated Roma' stereotype.

\section{Concluding Remarks}

Previous studies on occupational integration of Roma individuals have used explanatory models that emphasize the role of the culture of poverty and the lack of modernity of Roma communities. Socio-demographic indicators, such as the high school-dropout rate, the percentage of illiteracy, poor housing conditions and health of the Roma population have been stressed (Lazăr et al., 2014). These are of course valuable contributions in order to understand the challenges of entering the labour market for Roma individuals. However, as confirmed by Dincă (2014, p. 193), the challenge remains to de-ethnitise the socio-economic issues, and thereby stop this process of marginalization and discrimination. Therefore, in this article, we have demonstrated that there are issues connected to how the work inclusion system in Romania operates, that are of great importance too. By "keeping the institution in 
view", we have sought to bring out the "interface between individual lives and institutional relation" (McCoy, 2006, p. 109). Using institutional ethnography as a method of inquiry has made this possible by always looking out for traces of institutional practices in our interviews. The mapping of work (in a generous sense) being done and work knowledge of Roma individuals and other actors involved has enabled us to spot the textual practices and structural barriers that hinders labour market access. Seen through the lens of institutional ethnography and our informants the employment system in Romania in itself creates difficulties for Roma individuals striving to enter the labour market.

This article illustrates how both practices and discourse connected to the Romanian labour market produce and reproduce minoritising processes that preserve cultural and social order and marginalization. Formal hindrances and mutual mistrust reproduces the stereotypes of Roma individuals and maintains their informal role on the labour market as well as in society at large. This maintenance of informality further reinforces the stereotypes that stick to the Roma individuals as an ethnic group. Moreover, this reproduces the processes of minoritising which creates a greater divide between the majority and the Roma minority. Such processes of minoritising create exclusion in itself, and work counterproductively when it comes to including people on the labour market.

\section{Acknowledgments}

This article is a result of the project "Qualitative research on the professional integration of vulnerable groups- $E$-QUAL". The research leading to these results has received funding from EEA Financial Mechanism 2004-2014 under the project contract number SEE13/30.06.2014. The project is implemented by the West University of Timișoara, Romania in partnership with NORD University, Bod $\varnothing$, Norway.

\section{Conflict of Interests}

The authors declare no conflict of interests.

\section{References}

Alston, P. (2015). End-of-mission statement on Romania, by Professor Philip Alston, United Nations Human Rights Council Special Rapporteur on extreme poverty and human rights. Retrieved from http://www. ohchr.org

Berg, A. J., Flemmen, A. B., \& Gullikstad, B. (2010). Innledning: Interseksjonalitet, flertydighet og metodologiske utfordringer [Introduction: Intersectionality, ambigiousness and methodological challenges]. In A. J. Berg, A. B. Flemmen, \& B. Gullikstad (Eds.), Likestilte norskheter-Om kjønn og etnisitet
[Equal Norwegianness-On gender and ethnicity] (pp. 11-34). Trondheim: Tapir Akademisk Forlag.

Bisaillon, L., \& Rankin, J. M. (2013). Navigating the politics of fieldwork using institutional ethnography: Strategies for practice. Forum: Qualitative Sozialforschung/Forum: Qualitative Social Research, 14(1), Art. 14. Retrieved from http://nbn-resolving. de/urn:nbn:de:0114-fqs1301144

Brah, A. (2003). Diaspora, border and transnational identities. In R. Lewis \& S. Mills (Eds.), Feminist postcolonial theory. A reader (pp. 613-634). Edinburgh: Edinburgh University Press. (Original work published in 1996)

Campbell, M. (2015). Intersectionality, policy-oriented research and the social relations of knowing. Gender, Work and Organization. doi:10.111/gwao.12083

Costi, N. (2010). The spectre that haunts Italy: The systematic criminalization of the Roma and the fears of the Heartland. Romani Studies, 20(2), 105-136.

DeVault, M., \& McCoy, L. (2006). Institutional ethnography: Using interviews to investigate ruling relations. In D. E. Smith (Ed.), Institutional ethnography as practice (pp. 15-34). Lanham: Rowman \& Littlefield.

Dincă, M. (2014). Post socialist views on Gypsyness. The case of Roma communities in Romania. In C. Giordano, F. Ruegg, \& A. Boscoboinik (Eds.), Does east go west? Anthropological pathways through post socialism (pp. 183-196). Zurich: LIT Verlag.

European Commission. (n.d.). Shadow economy and undeclared work. Retrieved from http://ec.europa.eu/ europe2020/pdf/themes/07_shadow_economy.pdf

European Commission. (2015). Communication from the Commission to the European Parliament, the Council, the European Economic and Social Committee and the Committee of the Regions: Report on the implementation of the EU Framework for National Roma Integration Strategies 2015, COM(2015) 299. Brussels: European Commission.

European Union Agency for Fundamental Rights, \& United Nations Development Programme. (2012). The situation of Roma in 11 EU Member States. Survey results at a glance. Luxembourg: Publications Office of the European Union.

Fiscal Council. (2013). Annual report 2013. Bucharest: Casa Academiei Romane. Retrieved from http:// www.consiliulfiscal.ro

Halwachs, D. (2005). Roma and Romani in Austria. Romani Studies, 15(2), 145-173.

Hazans, M. (2011). Informal workers across Europe: Evidence from 30 countries (Discussion Paper No. 5871). Bonn: The Institute for the Study of Labor.

Lazăr, T., Dincă, M., Ungureanu, R., Sandvin Tveit, J., Fylling, I., Paulsen Breimo, J., . . . Bîrneanu, A. (2014). The compatibility between the current European and Romanian national framework of labour market integration of Roma. Retrieved from http://www.equal-see.ro 
McCoy, L. (2006). Keeping the institution in view: Working with interview accounts of everyday experience. In D. E. Smith (Ed.), Institutional ethnography as practice (pp. 109-125). Lanham: Rowman \& Littlefield.

McGarry, A. (2011). The dilemma of the European Union's Roma policy. Critical Social Policy, 32(1), 126136.

Milikowski, M. (2000). Exploring a model of deethnicization. The case of Turkish television in the Netherlands. European Journal of Communication, 15(4), 443-468.

Moisă, F., Rostaș, I. A, Tarnovschi, D., Rădulescu, I. S. D., \& Andersen, T. S. (2013). Raportul societăţii civile asupra implementării Strategiei Naţionale de Integrare a Romilor și a Planului de Acţiune al Deceniului în România în 2012 [The Report of the civil society regarding the implementation of the National Strategy for Roma Integration and the Action Plan of Roma Decade in Romania in 2012]. Budapest: Decade of Roma Inclusion Secretariat Foundation.

Preoteasa, A. M. (2015). Munca precara, solutie pentru populatia vulnerabila din mediul rural [Precarious work, a solution for the vulnerable population in rural areas]. Calitatea Vietii [Quality of Life], 26(1), 36-59.

Research Institute for Quality of Life. (2010). L@Egal2: Legal and equal on the labour market for the Roma communities. Diagnosis of the factors influencing the employment rate of the oma population in Romania. Bucharest: Valeriu IOAN-FRANC.

Romanian Government. (2015). Strategia Guvernului României de incluziune a cetățenilor români aparținând minorității rome pentru perioada 2015-2020 [The Strategy of the Romanian Government on the inclusion of the Romanian citizens belonging to Roma minority for the period 2015-2020] (Government Decision no. 18/2015, Romanian Official Gazette, Part I, no. 49 from 21.01.2015). Bucharest: Romanian Government.
Romani CRISS. (2011). Stereotipuri, prejudecăți și discriminare etnică: Perspectiva Romilor [Stereotypes, Prejudices and Ethnic Discrimination: The Perspective of Roma]. Bucharest: TOTEM Communication.

Shan, H. (2013). Skill as a relational construct: hiring practices from the standpoint of Chinese immigrant engineers in Canada. Work, Employment and Society, 27(6), 915-931.

Smith, D. E. (2005). Institutional ethnography. A sociology for people. Toronto: Altamira Press.

Surdu, M., \& Kovats, M. (2015). Roma identity as an expert-political construction. Social Inclusion, 3(5), 5-18.

Tarnovschi. D., Preoteasa, A.M., Șerban, M., Bîrsan, A., \& Hirian, R. (2012). Situaţia romilor în România, 2011. Între incluziune socială și migraţie. Raport de țară [The Roma situation in Romania, 2011. Between social exclusion and migration. Country Report]. Bucharest: Soros Foundation Romania.

The World Bank. (2012). Toward an equal start: Closing the early learning gap for Roma children in Eastern Europe (Working Paper No. 69729). Washington, DC: The World Bank.

Turner, S. M. (2006). Mapping institutions as work and texts. In D. E. Smith (Ed.), Institutional ethnography as practice. Lanham: Rowman \& Littlefield.

Vincze, E., Baciu, L., Harbula, H., Kozák, I., Lukács, G., Magyari, N., . . . Moraru, C. (2011). Accesul femeilor si barbatilor de etnie roma la munca decenta. Viata cotidiana, politici si proiecte [The access of Roma women and men to decent work conditions. Everyday life, social policies and projects]. Cluj: Desiree Foundation Publishing House.

Voicu, M. (2007). Nevoi si resurse in comunitatile de romi [Needs and resources in Roma communities]. Bucharest: Soros Foundation Romania.

Zhao. Y. (2012). Negotiating differences. Transnational adoption, Norwegianness and identity work (PhD dissertation). Bodø: University of Nordland.

\section{About the Authors}

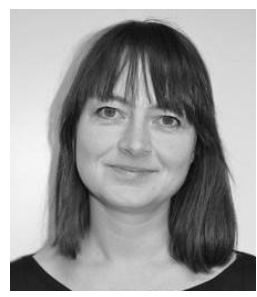

\section{Dr. Janne Paulsen Breimo}

Janne Paulsen Breimo is a post-doctoral fellow at NORD University (Norway). She holds a Master in Political Science and a Ph.D. in Sociology. She has published on case management instruments in rehabilitation, employment and the transition to adult life for young people cared for by child protection services. She is currently chair of the European Sociological Association's (ESA) Research Network 26 (Sociology of Social Policy and Social Welfare), and coordinator for the Nordic Network on Institutional Ethnography.

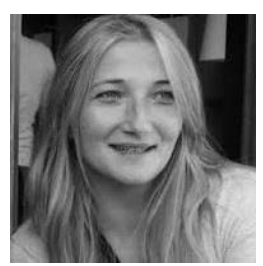

\section{Dr. Elena Loreni Baciu}

Elena Loreni Baciu is a Lecturer at the West University of Timisoara (Romania), and President of the Institute of Research for Social Development and Innovation since 2012. She has published mainly on topics related to employment and employment policies for vulnerable groups and also published and co-edited books on various topics in the area of social work. Among her areas of expertise: employment of vulnerable groups and public-private collaboration in the development of social services. 